University of Rhode Island

DigitalCommons@URI

Open Access Master's Theses

1969

\title{
Characterization of the Effect of Methylchloroform Inhalation on Hepatic Drug Metabolism in the Rat
}

Arnold Merwin Olshan

University of Rhode Island

Follow this and additional works at: https://digitalcommons.uri.edu/theses

\section{Recommended Citation}

Olshan, Arnold Merwin, "Characterization of the Effect of Methylchloroform Inhalation on Hepatic Drug Metabolism in the Rat" (1969). Open Access Master's Theses. Paper 214.

https://digitalcommons.uri.edu/theses/214

This Thesis is brought to you for free and open access by DigitalCommons@URI. It has been accepted for inclusion in Open Access Master's Theses by an authorized administrator of DigitalCommons@URI. For more information, please contact digitalcommons-group@uri.edu. 
CHARACTERIZATION OF THE EFFECT OF METHYLCHLOROFORM INHALATION ON HEPATIC DRUG METABOLISM IN THE RAT

B Y

ARNOLD MERWIN OLSHAN

A THESIS SUBMITTED IN PARTIAL FULFILLMENT OF THE

REQUIRFMENTS FOR THE DEGREE OF

MASTER OF SCIENCE

IN

PHARMACOLOGY

University of Rhode Island 
ABSTRACT TITLE

;

EFFECT OF METHYLCHLOROFORM ON DRUG METABOLISM 


\section{ABSTRACT}

Olshan, Arnold Merwin. M.S., University of Rhode Island, August 1969. Characterization of the Effect of Methylchloroform Inhalation on Hepatic Drug Metabolism in the Rat. Major Professor: Dr. George C. Fuller.

Male rats were exposed to methylchloroform (1,1,1-trichloroethane) vapors (concentration about 2500 PPM) for 24 hours and the effects of this treatment on drug responses and hepatic drug metabolism studied 24 hours later to determine the effect of metrylchloroform on inducible hepatic drug-metabolizing enzymes.

Exposure to methylchloroform vapor signjicantly decreased the sleeping time of the rat in response to hexobarbital $1120 \mathrm{mg} / \mathrm{kg}$, i.p.) and zoxazolamine (80 $\mathrm{mg} / \mathrm{kg}, \mathrm{i} . \mathrm{p.})$.

Rat blood and liver methylchloroform cortent measured immediately following exposure suggested that the effects of methy chloroform were caused by a systemic action.

Experiments with $9000 \times \mathrm{G}$ supernatants indicated that the metabolism of hexobarbital was significantly increased following exposure to methylchloroform.

Significantly increased $\mathrm{N}$-demethylation of aminopyrine, accompanicd by increased amounts of nicrosoma! co-binding pigraent 
1 (cytochrome $\mathrm{P}-450$ ) and microsomal NADPII-cytochrome $c$ reductase were observed in in vitro experiments using hepatic microsomal fractions from rats exposed to.methylchloroform. The spectral properties of the CO-binding pigment in animals exposed to methylchloroform did not differ from controls.

Pretreatment with actinomycin D or cycloheximide prevented the decrease in the hexobarbital sleeping time in rats cxposed to methylchloroform. Further studies demonstratec that pretreatmiant with cycloheximide prevented the increase in metabolism of aminopyrine by rats exposed to methylchloroform.

- These observations suggest that the increased drug-metabolizing activity in the exposed rats is due to an accelerated synthe sis of the hepatic drug-metabolizing system. The inducing effects of methylchloroform appear to be related to those produced by phenobarbital. 


\section{MASTER OF SCIENCE THESIS}

OF

\section{ARNOLD MEIRWIN OLSHAN}

Approved:

Thesis Committec:
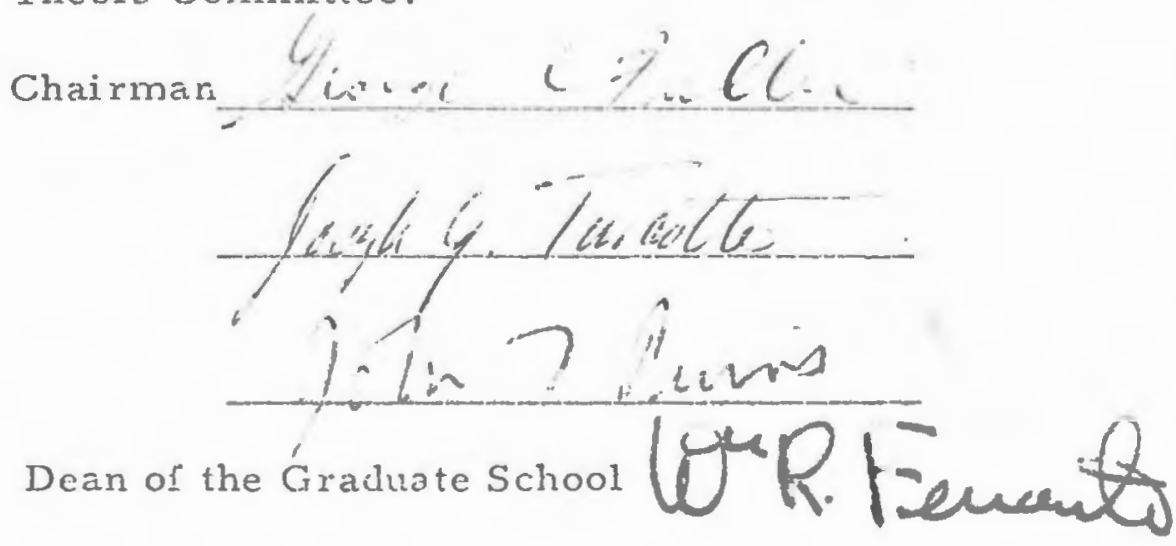

UNIVERSITY OF RHOIJE ISIAAND

1969 


\section{ACKNOWLEDGEMENTS}

The author conveys his sincere appreciation to Drs. George C. Fuller and Harbans Lal for their invaluable guidance throughout the duration of this study. Also acknowledged is the counsel and equipment made available by Drs..John L. Purvis, Joseph G. Turcotte, and Charles E. Olney.

The author wishes to thank Messrs. Surendra K. Puri and Robert Louis-Ferdinand for assistance in certain phases of this investigation.

Appreciation is extended to the author's wife for her forbearance during his terure in graduate school.

Financial support for this investigation was provided by the Office of Naval Research under Contract N00014-68-A-0215 and by an NSF Predoctoral fellowship. 
ILIST OF TABI.ES...................... v

ABSTRACT.......................... vi

INTRODUCTION. ........................ 1

LITERATURE SURVEY..................... 3

Methylchloroform...................... 3

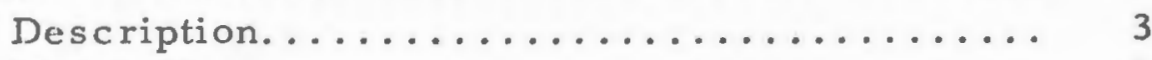

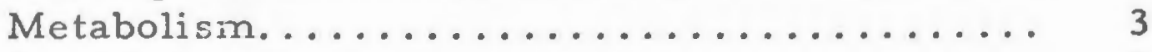

Effects in Animals................. 3

Effects in Man.................... 4

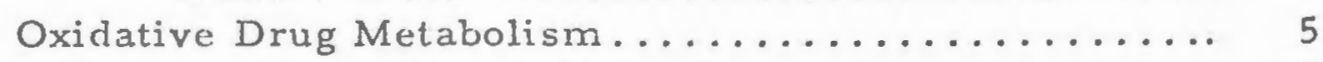

Induction of Drug-Metabolizing Enzymes .......... 8

Inhibitors of Protein Synthesis................ 11

EXPERIMENTAL. ....................... 12

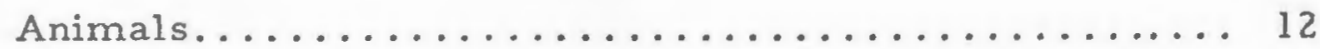

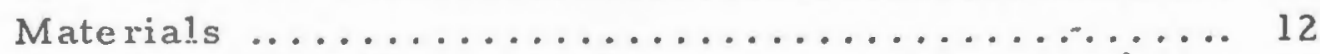

Inhalation Chamber $\ldots \ldots \ldots \ldots \ldots \ldots \ldots \ldots \ldots \ldots$

Methylchloroform Exposure................ 14

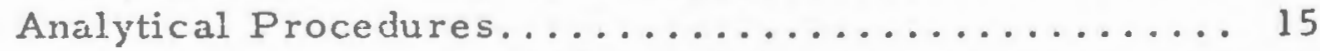

Determination of Methylchloroform in the Exposure Chamber.................... 15

Determination of Methylchloroform in the Blood. 15

Determination of Sleeping Time.......... 16

Collection of Biological Samples.......... 17

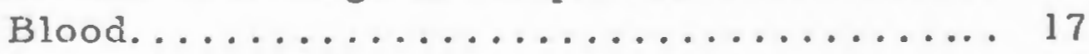

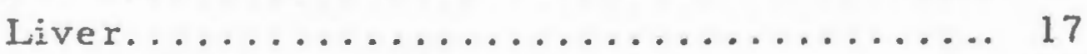

Preparation of Liver Microsomes......... 17

Preparation of 9000 $\times$ G Supernatants......... 18

Deterraination of Protein............. 18

Jetermination of In Vitro N-demethylation of

fininopyrine ...................... 19

Determination of In Vitro Metabolism of

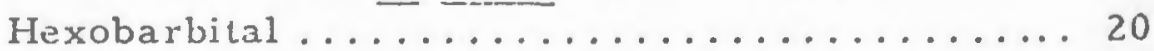

Determination of In Vitro Metabolism of Zoxa-

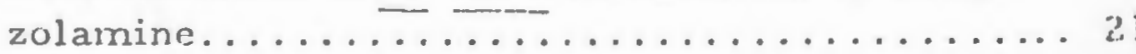


EXPERIMENTAL (Cont'd.)

Determination of Microsomal NADPH -

Cytochrome $c$ Reductase Activity ..........

Determination of CO-Binding Pigment (P-450).

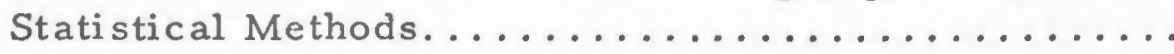

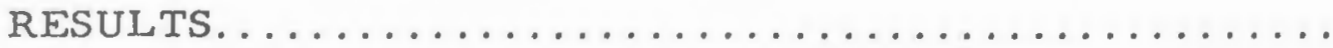

Methylchloroform Concentration in the Exposure

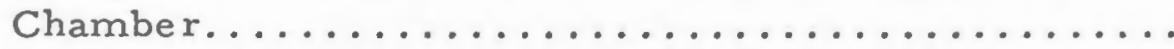

Methylchloroform Content of Rat Blood and Liver Following 24 Hour Exposure ...............

Effect of Methylchloroform on Hexobarbital Sleeping

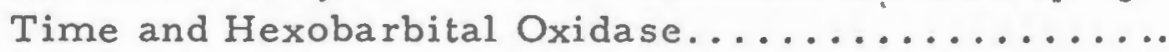
Effect of Methylchloroform on Zoxazolamine Slecping Time and Zoxazolamine Hydroxylase Activity....... Effects of Methylchloroform on Several Hepatic Microsornal Parameters of Drug Metabolism.......... Effects of Cycloheximide on Various Parameters of Hepatic Drug Metabolism in the Male Rat......... Effect of Actinomycin D on Hexobarbital Sleeping

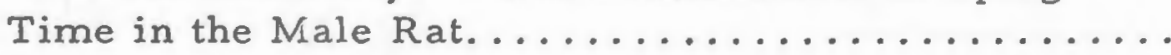

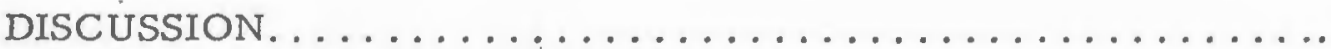

SUMMARY AND. CONCLUSIONS................

BIBLIOGRAPHY ......................

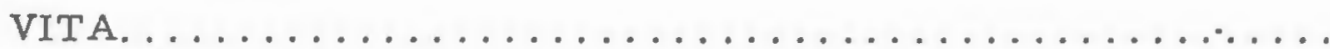


1 Analysis of Methylchloroform in the Blood and Liver of Male Rats.......................

$2 A$ Effect of Methylchloroform on Hexobarbital Sleeping Time in the Male Rat..................

2B Effect of Methylchloroform on the Metabolism of Hexobarbital in the Rat Liver $9000 \times$ G Supernatants

3A Effect of Methylchloroform on Zoxazolamine Sleeping

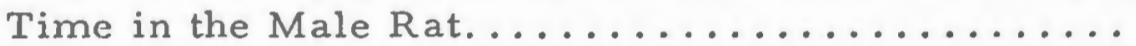

3B Effect of Methylchloroform on Z jxazolamine Hydroxylase Activity in the Male Rat...............

4 Effects of Methylchloroform on Several Hepatic Microsomal Constituents in the Male Rat.........

5 Effects of Cycloheximide on Various Parameters in the Male Rat........................

6A Effect of Actinomycin D on Hexobarbital Slecping Time

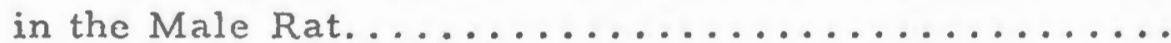

6B Effect of Actinomycin D on Hexobarbital Sleeping Time in the Male Rat....................... 


\section{INTRODUC'TION}

Humans may be exposed to small concentrations of methylchloroform (1,1,1-trichloroethane) vapors for extended periods of time because of its wide use as an organic solvent and degreaser. Knowledge of the possible mechanisms of toxic activity of methylchloroform would facilitate the development of a method of detecting early signs of toxicity of this liquid.

An increase in activity which appears to represent ar increased concentration of enzyme protein is referred to as "enzyme incluction." Induction of hepatic drug-metabolizing enzymes leads to accelerated biotransformations of drugs in vivo the refore altering the duration and intensity of drug actions in animals and man (Conney, 1967).

Studies by Gillette (1963) and Eooth and Gillette (1962) have shown that foreign compounds in rats may enhance the activity of drug-metabolizing enzymes by-at lcast three different mecharisms: one evoked by anabolic steroids, a second by polycyclic hydrocarbone, and a third by phenobarbital.

These three types of inducers stimulate varied pathways of drug metabolism by liver microsornes. This research was conducted to determine if methylchloroform is an inducer of hepatic drug-. metabolizing enzymes and to jeintify met!rylchloreform with one 
of the above three types of inducers if the above hypothesis proved correct.

The following parancters of hepatic drug metabolism were investigated: in vivo studies of hexobarbital and zoxazolamine sleeping time; in vitro metabolic studies of zoxazolamine hydroxylase, hexobarbital oxidase, aminopyrine demethylase, NADPH cytochrome $\subseteq$ reductase, and $\mathrm{CO}$-binding pigment; and studies of liver weight and microsomal protein. Inhibitors of protein synthesis (actinomycin D and cycloheximide) were used as tools to block the effect of methylchloroform on hepatic drug metabolism and thereby establish that an induction process does occur in response to methylchloroform exposure. 


\section{LITERATURE SURVEY}

Methylchloroform

\section{Description}

Methylchloroform is a chlorinated hydrocarbon. It is a highly volatile, colorless liquid with a chloroform type odor (Browning, 1965). Metabolism

Methylchloroform is readily absorbed through the lungs (Williams, 1959). Studies by Hake et al. (1960) showed that methylchloroform was very stable in the body, and while a large part of an intravenous dose was excreted unchanged by the lungs, a very small. part was metabolized to chloroethanol and excreted in the urine as the glucuronate.

\section{Effects in Animals}

The primary toxic effect of methylchloroform is central nervous system depression producing anesthesia. Lethal dosage causes central nervous systen depression resulting in respiratory paralysis (Adams et al., 1959). At the aresthetic level methylchloroform sensitizes the heart to epincphrine causing an idioventricular rhythm $\{$ Rennick et al., 1949). With chronis exposure (500 PPM, 7 hours a day, 5 days a week for 6 months) no evidence of impairment of growth or health was observed in rats, rabbits, guinea pigs, and monkeys. In another study at 2000 PPM for 3 months, the only animal species in 
which organic injury was observed was the female guinea pig. These organic lesions included slight inflammation of the lungs and fatty changes in the liver (Torkelson et al., 1958). The lethal dose in rats by inhalation is 30,000 PPM for 6 minutes; 15,000 PPM for $1-1 / 2$ hours; and 8000 PPM for 7 hours (Adams et al. , 1950). Effects in Man

Stewart et al. (1961) have reported data obtained when seven human subjects were exposed to constantly increasing concentrations of methylchloroform up to 2650 PPM over a period of 15 minutes. At 1000-1100 PPM and 1900-2000 PPM mild eye irritation and throat irritation was noted, respectively, in 6 of the 7 subjects. At 2650 PPM 2 subjects were unable to stand and 3 subjects were very lightheaded but able to stand. In another test at 910 PPM for 35 misulcs, lightheadedness was experienced in one of two subjects. These subjective and physiological responses agreed with the results reported by Torkelson et al. (19,58).

Stcwart et al. (1961) also measured the blood ard urine of subjects exposed to methylchloroform. Depending on lenglh of exposure anl concentration of methylchloroform, blood samples contained up to 10 PPM and urine samples up to 2 PPM at the termination of exposure. Thirty minutes after exposure only trace arnounts ( 1.0 PPM) of methylchloroform could be found in the blood or urine. 
Previous investigations (Lal and Shah, 1968) have suggested a possible role of methylchloroform as an inducer of hepatic drugmetabolizing enzymes in rodents.

\section{Oxidative Drug Metabolism}

Early investigations have established that the enzymatic metabolism of foreign compounds is carried out by enzymes located in the microsomal fraction of the liver and are dependent on the generation of NADPH by the soluble fraction. Although the mechanism of drug oxidation by microsomes is not yet clear, Mason (1957) proposed that the oxidative reaction is coupled to a microsomal electron transport system operating between NADPH and oxygen. Siekevitz (1965) has reviewed the microsomal electron transport systems and suggests that the-following pathway may be operative for the passage of electrons from NADPH to oxygen:

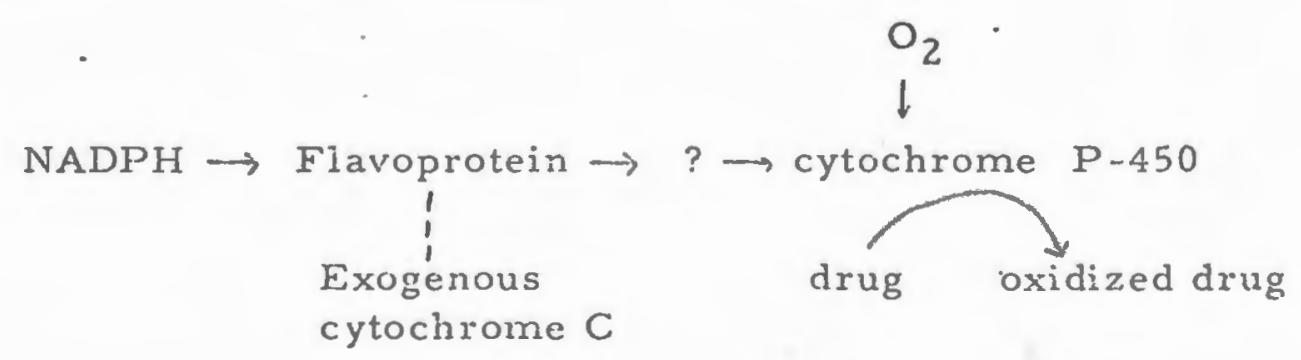

Cytochrome P-450 is the microsomal hemoprotein that is believed to function as the oxygen-activating enzyme and te rminal oxidase for hydroxylating a number of drugs and steroids. Evidence for the existence of this cytochrome was first presented by Klingenberg (1958) 
and Garfinkel (1948) and has since been extensively studicd by Omura and Sato (1964). The hemoprotein can be characterized by its reactivity with carbon monoxide and ethyl isocyanide. The pigment has been termed cytochrome $\mathrm{P}-450$ because in the reduced form reaction with carbon monoxide exhibits an absorption maximum at $450 \mathrm{m \mu}$.

In 1965 Cooper et al. presented evidence for the participation of cytochrome P-450 in NADPH dependent microsomal systems responsible for the metabolism of many drugs. They showed that the liver microsomal oxidation of codeine, 4-monomethylaminoantipyrine, and acetanilide was inhibited by carbon monoxide and that this inhibition could be reversed by monochromatic light at $450 \mathrm{m \mu}$ or by oxygen. Kuntzman et al. (1968) implicated cytochrome P-450 as the terminal oxidase for steroid hydroxylation of testosterone by liver enzymes with his findings that the hydroxylation of testosterone by liver microsomes could be inhibited by carbon monoxide and that this inhibition was reversed by monochromatic light.

At the present time there is a question as to whether liver microsomes contain one or more different hemoproteins that function in hydroxylation reactions. Remmer and Merker (1965) and Sladek and Mannering (1966) have shown that phenobarbital or 3-methylcholanthrene increases the concentration of cytochrome P-450. Alvares et al. (1967) and Kuntzman et al. (1968) have shown that in 3-methylcholanthrene treated rats, carbon monoxide interacts with the 
reduced microsomal hemoprotein to give an absorption maximum at $448 \mathrm{~m} \mu$ instead of an absorption maximum at $450 \mathrm{~m} \mu$ which is seen in the untreated and phenobarbital treated rats. Imai and Sato (1.966) also presented evidence for two forms of cytochrome P-450 based on different spectral properties seen with phenobarbital or 3-methylcholanthrene treated rats when ethyl isocyanide was used as the ligand for the reduced hemoprotein. It is feasible that 3-methylcholanthrene or its metabolite binds to the hemoprotein, and this bound hemoprotein possesses spectral properties different from untreated or phenobarbital treated rats. Other possibilities are the induced synthesis of a spectrally different hemoprotein or in conversion of one form of hemo protein to another form in the presence of the inducer. Kuntzman et al. (1968) and Alvares et al. (1967) have shown that pretreatment of rats with ethionine or actinomycin $D$ prevented the peak shift to $448 \mathrm{~m} \mu$ caused by 3 -methylcholanthrenc. In vivo administration of 3-methylcholanthrene to animals 2 hours prior to sacrifice or in vitro addition of 3-methylcholanthrene to microsomal suspension did not cause any spectral changes (Kuntzman et ㄹ‥, 1968). These results suggest the synthesis of a new hemoprotein but the true solution will have to wait for solubilization and purification of the hemoprotein(s) found in normal, phenubarbital and 3-methylcholanthrene animals.

Jick and Shuster (1966), Ernster and Orrenius (1965) and Remmer 
and Merker (1965) have reported that treatment with phenobarbital increases liver microsomal NADPH cytochrome $\underline{c}$ reductase levels in the rat almost two fold. Von Der Decker and Hultin (1960) and Kato and Takayanaghi (1966) demonstrated that the administration of 3-methylcholanthrene had no effect on NADPH cytochrome $\subseteq$ reductase. Thus, NADPH-cytochrome $\subseteq$ reductase and $\mathrm{P}-450$ are established as components of the oxidative drug-metabolizing system of liver microsomes and the activity of same should be evaluated in the presence of suspected induction of the drug-metabolizing enzymes.

\section{Induction of Drug-Metabolizing Enzymes}

At the present time at least 200 chemicals have tecil identificd as inducers of drug-metabolizing enzymes (Conney, 1967). In studies where two different types of inducers (i.e., phenobarbital and 3-methylcholanthrene) were used together, liver microsomes were more active than studies where each was used alone or where two drugs of a similar type (i.e., 3-methylcholanthrene and 3,4benzpyrene) were used together (Gillette, 1963). A similar in vitro study using ACTH and 3,4-benzpyrene (with zoxazolamine as the substrate) and phenobarbital and methyl testosterone (with monomethyl-4-amino antipyrine as the substrate) showed a stimulation of drug metabolism more than maximum doses of 3,4-benzpyrene or phemobarbital could produce. This indicated a third possible type of induce $r$, the anabolic steroids. 
These three general types of inducers stimulate varied pathways of metabolism by liver microsomes. There is a large overlap in the types of reactions and in specific pathways induced with individual drugs or chemicals. In general, 3-methylcholanthrene stimulates a more limited group of reactions than phenobarbital or the anabolic ste roids.

Conney et al. (1960) and Kato and Takayanaghi (1966) have shown that 3 -methylcholanthrene increases the metabolism of zoxazolamine in rats but has no effect on the in vitro metabolism of hexobarbital or aminopyrine, while phenobarbital significantly increased the metabolism of all three drugs. Anabolic steroids increase the metabolism of hexobarbital (Booth and Gillette, 1962); stimulate the N-demethylation of aminopyrine (Kato and Takayanaghi, 1966):; but do not significantly alter zoxazolamine hydroxylase activity (Gillette, 1963; Kato and Takayanaghi, 1966).

Hexobarbital sleeping time is often used as an accurate indicator of microsomal drug metabolism. The duration of hexobarbital hypnosis in rats is significantly shortened by treatment with pherobarbital (Comney et al. , 1960) and anabolic stcroids (Booth and Gillette, 1962) but is not altered by 3 -methyl cholanthrene type drugs (Conney et al. , 1960). The duration of z.oxazolamine paralysis is significantly reduced by treatment of rats with phenobarbital or 3-methylcholanthrene (Conney et al., 1960), or in mice by anabolic steroids (Novick et al. , 1960 ). 
The time required for the various types of inducers to produce an effect differs. While phenobarbital produces stimulatory effects on enzyme activity in 1-4 days (Conney et al. , 1960), polycyclic hydrocarbons take only 3 to 6 hours with maximum effects observed in 24 hours (Conney et al., 1956). Methyl testosterone induction is not apparent except afte $r$ prolonged administration (weeks) (Booth and Gilette, 1962).

Phenobarbital, polycyclic hydrocarbons, and anabolic steroids may increase the levels of liver microsomal enzymes by stabilizing these enzymes as well as by accelerating the rate of synthesis. Kinetic studies with mouse tis sue have shown that phenobarbital causes an increase in liver NADPH-cytochrome c reductase levels by increasing the rate of synthesis and by decreasing the rate of breakdown (Rubin et al. , 1964).

While phenobarbital causes a $20-40 \%$ increase in microsomal protein per gram of liver (Conney et al., 1960), 3-methylcholanthrene (Conney et al. , 1960) and the anabolic steroids (Booth and Gillette, 1962) cause no increase in microsomal protein per gram of liver. Phenobarital and 3-methylcholanthrene administered to rats for 2 to 3 days increased the liver to body weight ratios 20 to $30 \%$ but prolonged treatment with anabolic steroids did not significantly change this ratio.

Electron microscopic examination of smooth surfaccd 
endoplasmic reticulum is a useful index of drug induced changes in liver microsomal enzyme levels. Phenobarbital causes proliferation of smooth surfaced endoplasmic reticulum in liver cells but has little effect on rough surfaced endoplasmic reticulum, while 3-methylcholanthrene has little or no effect on smooth surfaced endoplasmic reticulum (Remmer and Merker, 1965).

\section{Inhibitors of Protein Synthesis}

The induction of drug-metabolizing enzyme activity by phenobarbital or 3-methylcholanthrene is blocked by ethionine (Conney et al. , 1956; Conney et al., 1960); puromycin (Gelboin and Blackburn, 1964; Orrenius et al. , 1965); and actinomycin D (Gelboin and Blackburn, 1964; Orrenius et al. , 1965).

These inhibitors block protein synthesis by various mechanisms. Ethionine appears to block protein synthesis by decreasing the A levels in the liver (Villa-Trevino et al. , 1963); puromycin has been reported to block the transfer of soluble RNA-bound amino acid into microsomal protein (Yarmolinsky and De La Haba, 1956); and actinomycin D binds to DNA, and therefore may act by blocking the DNA directed synthesis of nuclear RNA required for protein synthesis (Reich et al. , 1961). However, Reich (1964) has also reported that actinomycin D inhibits strand separation of helical DNA and suppresses DNA polymcrase activity. Thus it is clear that actinornycin D 
activity is exerted at the level of the nucleus.

Cycloheximide, another known inhibitor of protein synthesis, is reported to act on extranuclear components. Korner (1966) reported that the liver ribosomes of rats given cycloheximide by intraperitoneal injection incorporate less amino acids into protein than ribosomes from control rat liver. Their experiments showed that cycloheximide treated animals incorporated $95 \%$ less 1 -leucine $-{ }^{14} \mathrm{C}$ into ribosomal proteins. Studies by Harris et al. (1968) show that a single dose of cycloheximide in rats inhibited the incorporation of uridine $-{ }^{3} \mathrm{H}$ into nucleolar RNA with maximum inhibition at 24 hours. 


\section{EXPERIMENTAL}

\section{Animals}

Male Sprague-Dawley derived rats obtained from Charles River Breeding Laboratories (Wilmington, Mass.), weighing between 60 and $100 \mathrm{gm}$. we re used throughout the course of this study. The animals were maintained on commercial laboratory chow and water ad libitum. Rats were used not earlier than four days after being received from the supplier via commercial shippers or were used the following day when personally picked up at the source of supply. Rats we re maintained in a room with controlled temperature and alternating 12 hour periods of light and darkness. All drugs we re adrninistered via the intraperitoneal route.

\section{Materials}

Analytical reagent grade chemicals o.r equivalent were used throughout this study. Co-factors (NADP, NADPH, glucose-6phosphate, cytochrome $c$, and glucose-6-phosphate dehydrogenase) and crystalline bovine serum albumin we re purchased from Calbiochem. The drugs used in this investigation were obtained from their respective manufacturers. The toluene used was the $25 \%$ fraction that remained after distillation. 


\section{Inhalation Chamber}

The chamber consisted of a flat bottom cylindrical glass jar $\left(12^{\prime \prime} \times 18^{\prime \prime}\right)$ placed horizontally on a wooden platform. The open end of the jar was closed by a wooden frame with a cork ring. The wooden frame was fitted with a removable circular wooden hatch (9/2" diameter) for the introduction of animals and a 4-hole rubber stopper (2" diameter). Two copper tubes reaching the end of the jar, a copper tube reaching only the front of the jar, and a thermometer were inserted through these holes.

\section{Methylchloroform Exposure Protocol}

The animals were placed into the inhalation chamber onto a perforated platform. The exposure atmosphere was forned by the passing of air at a rate of 0.2 liters/minute through a gas drying bottle containing methylchloroform and subsequent dilution with air at a flow rate of 10 liters air/minute. Equilibrium of the chamber atmosphere was achieved by introducing the air mixture through the long copper tubes described above with venting via the short copper tube. The desired flow rates were maintained by the use of flow meters (Hoke, Inc., Style 993). The animals were allowed free access to food and water for the entire period of exposure. At the end of the exposure, they were transferred to battery cages until used. The exposure protocol used for all studies relating to drug metabolism was a single 24 hour exposure with observations made 24 hours after the termination 
of cxposure. Those animals used for lic assay of liver and blood were sacrificed immediately upon removal from the chamber. Analytical Procedires:

Determination of Methyl chloroform in the Exposure Chamber

An Aerograph Autoprep A-700 Gas Chromatograph (Variens, Inc. , California) equipped with a the rmal conductivity detector with a Specdomax $X$ recorder was used to measure the concentration of methylchloroform in the exposure chamber. An $18 \%$ Hi Eff-3BP on $60 / 80$ Chromosorb w A-10 column (neopertyl succinatc on acid washed chromosorb) obtained from Applied Science (Philadolpinia, Ia.) was used. The column temperature was set to about $73^{\circ} \mathrm{C}$, injector temperature to about $130^{\circ} \mathrm{C}$, and detector temperature to about $88^{\circ} \mathrm{C}$. The filament was set at $200 \mathrm{ma}$. Helium with a gas floiv of $60 \mathrm{~mm} / \mathrm{minute}$ was used as the carrier gas. For the standard, $2 \mu l$ of pure methylchloroform was injccied into the instrument at an attenuation of 16. For the sariple, $20 \mathrm{ml}$ of chamber air was injected into the chawber at an attenution of 2 . The areas uncier the standard and sample peaks were calculated and ppra were determined using the equivalent $1 \mathrm{mg} /$ liter $=183$ ppm (Browning, 1965).

\section{Detcrumination of Methyl chloroform in the Bilood}

The blood was collected from rats as described beion and extracted with 2 volumes of toinesc. An Aerograph Hy Fi Model 600D-Jinear tomperature Frogramnier Mudel 326 equiprad nith an 
Electron Capture Detector with a tritium source and a Honeywell Electronic 118 Recorder was used. A 20\% GP 29A, ABS 60/70 column (20\% carbowax $20 \mathrm{M}$ terminated with terephthalic acid groups on acid, alcohol, base washed diatomaceous earth) obtained from Analabs, Inc. (Hamden, Conn.) was used. Nitrogen was used as the carrier gas at a flow that permitted maximum separation. Since the determination was not linear, the following methylchloroform concentrations were used as standards: $0.1,0.5,1.0,2.0,4.0,5.0,6.0,8.0,10.0 \mathrm{ppm}$ and a standard curve drawn. Two $\mu l$ of all samples and standards were injected into the instrument. Peak heights were measured and the sample concentrations determined by extrapolation from a standard curve.

Determination of Sleeping Time

Duration of pharmacologic response of the depressant drugs employed in this study was measured using sleeping time as an endpoint. Animals were weighed, marked, and placed into cages im.. mediately prior to use. Hexobarbital solutions were prepared in distilled water with a small amount of $1 \mathrm{~N} \mathrm{NaOH}$ in a concentration which permitted the administration of $10 \mathrm{ml} / \mathrm{kg}$. Zoxazolamine was prepared as a suspension in $0.5 \%$ methylcellulose in a concentration which also permitted the administration of $10 \mathrm{ml} / \mathrm{kg}$. Sleeping time was taken as the length of time between the loss and regaining of the righting reflex. 


\section{Collection of Biological Samples}

Blood. Methylchloroform-treated animals were sacrificed immediately upon removal from the exposure chamber (exposed $24 \mathrm{hrs}$. at atmospheric concentration of about 2500 ppm methylchloroform) by decapitation and the free-flowing blood collected in a beaker containing a few drops of $33 \%$ sodium citrate solution. The blood was frozen until assayed. Blood from control rats was collected in the same manner.

Liver. Immediately after decapitation and collection of blood (above), the livers were removed, homogenized in 1 volume of $0.1 \mathrm{M}$ phosphate buffer $(\mathrm{pH}-7.4)$ and extracted with 2 volumes of toluene. These samples were stored in the freezer until assayed for methylchloroform. Control experiments established that no methylchloroform was lost during storage.

Preparation of Liver Microsomes

Animals were sacrificed by cervical dislocation, the abdomen opened and the livers perfused with $1.15 \% \mathrm{KCl}$ solution via the hepatic portal vein. The livers were quickly excised, weighed, minced with scissors, and homogenized for 60 seconds in 2 volumes of ice cold $0.1 \mathrm{M}$ phosphate buffer ( $\mathrm{pH} 7.4$ ) in a motor driven coaxial homogenizer. The homogenates were centrifuged for 30 minutes at $0^{\circ}$ and $10,000 \mathrm{rpm}$ (9000 $\times$ G ave.) in an International model B -60 preparative ultracentrifuge (rotor $\# 874$ ). The supernate was decanted and centrifuged at 
$30,000 \mathrm{rpm}(78,000 \times \mathrm{G}$ ave.) for one hour to obtain the microsomal fraction. The microsomal pellet was washed and resuspended in cold $0.1 \mathrm{M}$ phosphate buffer $(\mathrm{pH} 7.4)$ in a volume equivalent to that of the original liver. Aliquots of the microsomal suspension and $78,000 \times \mathrm{G}$ supernatants were frozen and stored at $-10^{\circ} \mathrm{C}$ until assayed.

\section{Preparation of $9000 \times$ G Supernatants}

Rats were sacrificed by cervical dislocation, and the livers homogenized as described above. The $9000 \times$ G supernate fraction was taken after centrifugation at $0^{\circ} \mathrm{C}$ at $10,000 \mathrm{rpm}$ in an International \#874 rotor for 30 minutes and stored at $-10^{\circ} \mathrm{C}$ until assayed. Determination of Protein

$9000 \times$ G supernatant and microsomal protein were estimated by the method described by Lowry et al., (1951). About $165 \mathrm{mg}$ of liver equivalent for the $9000 \times \mathrm{G}$ supernatants and about $333 \mathrm{mg}$ of liver equivalent for microsomes were placed into $50 \mathrm{ml}$ centrifuge tubes containing enough $0.5 \mathrm{~N} \mathrm{NaOH}$ for a final volume of $10.0 \mathrm{ml}$. The tubes were placed into a water bath and heated at $75^{\circ} \mathrm{C}$ until dissolution was complete. Standard solutions of freshly prepared crystalline bovine serum albumin in $0.5 \mathrm{~N} \mathrm{NaOH}$ and a blank consisting of $0.5 \mathrm{~N} \mathrm{NaOH}$ soluticn were carried through the entire procedure. When the tis sue was completely dissolved, an $0.2 \mathrm{ml}(9000 \times \mathrm{G}$ supernatants) or $0.4 \mathrm{ml}$ (microsomes) aliquot was withdrawn and placed into 
a second tube containing $1.0 \mathrm{ml}$ of $0.5 \mathrm{~N} \mathrm{NaOH}$. Five $\mathrm{ml}$ of reagent $\mathrm{A}$ (1. $0 \mathrm{ml}$ of $2.7 \%$ potassium tartrate $\frac{1}{2} \mathrm{H}_{2} \mathrm{O}, 1.0 \mathrm{ml}$ of $1.0 \% \mathrm{CuSO}_{4} \cdot 5 \mathrm{H}_{2} \mathrm{O}$, and $100 \mathrm{ml}$ of $\left.2.0 \% \mathrm{Na}_{2} \mathrm{CO}_{3}\right)$ was added and the tubes mixed and allowed to stand at room temperature for 20 minutes. Then $0.5 \mathrm{ml}$ of reagent B (commercial folin phenol reagent diluted to $1 \mathrm{~N}$ with distilled water) was added and the tubes mixed and allowed to stand at room temperature for 40 minutes before being read in a Beckman DB-G grating spectrophotometer at $500 \mathrm{mp}$ versus an $0.5 \mathrm{~N} \mathrm{NaOH}$ blank. Determination of In Vitro $\mathrm{N}$-demethylation of Aminopyrine

The method of McMahon and Easton (1962) was employed to measure the formaldehyde formed during the in vitro $\mathrm{N}$-demethylation of aminopyrine by liver fractions. A typical incubation mixture contained $1.0 \mathrm{ml}$ of $9000 \times \mathrm{G}$ supernatant or $1.0 \mathrm{ml}$ of $78,000 \times \mathrm{x}$ super natant and $1.0 \mathrm{ml}$ of microsomes (about $333 \mathrm{mg}$ of liver equivalent), $10 \mu$ Moles of aminopyrine (substrate), $45 \mu$ Moles of semicarbazide, $30 \mu$ Moles of glucose-6-phosphate, $4 \mu$ Moles. of NADP, $50 \mu$ Moles of $\mathrm{MgCl}_{2} \cdot 6 \mathrm{H}_{2} \mathrm{O}, 50 \mu$ Moles of nicotinamide, and $300 \mu$ Moles of $0.1 \mathrm{M}$ phosphate buffer (pH 7.4) in a total volume of $5.0 \mathrm{ml}$ in $25 \mathrm{ml}$ erlenmyer flasks. Parallel incubation flasks containing $1.32 \mu$ Moles of formaldehyde (standard) in place of substrate and distilled water (blank) in place of substrate were carried through the entire procedure. The flaslis were incubated in a Dubnoff shaker at $37^{\circ} \mathrm{C}$ under air for 30 minutes. At the end of the incubation period, the flask contents 
were poured into centrifuge tubes. Four $\mathrm{ml}$ of $10 \%$ zinc chloride (prepared with $\mathrm{CO}_{2}$-free water) were added and the tubes mixed. Two $\mathrm{ml}$ of a saturated solution of barium hydroxide were added and the samples again mixed. The tubes were centrifuged for about 10 minutes and $5.0 \mathrm{ml}$ aliquots of the clear supernates were transferred to clean centrifuge tubes containing $2.0 \mathrm{ml}$ of double strength $\mathrm{Nash}$ reagent (0.04 $\mathrm{M}$ acetylacetone in $0.4 \mathrm{M}$ ammonium acetate $-0.1 \mathrm{M}$ acetic acid). the contents we re mixed and the tubes heated in a water bath at $60^{\circ} \mathrm{C}$ for 30 minutes. The colors were read against the blank using a Beckman DB-G grating spectrophotometer at $410 \mathrm{m \mu}$. Determination of In Vitro Metabolism of Hexobarbital

The method described by Cooper and Brodie (1953) was used to measure the disappearance of hexobarbital from incubation media. The basic incubation mixture and conditions as previously described were used with semicarbazide omitted and hexobarbital as the substrate. After incubation for 30 minutes at $37^{\circ} \mathrm{C}$ in a Dubnoff shaker, the ilisk volumes we re transferred to $50 \mathrm{ml}$ centrifuge tubes containing $1.0 \mathrm{gm} \mathrm{NaCl}$ and $1.5 \mathrm{ml}$ phosphate buffer $(\mathrm{pH}-5.5)^{2}$.

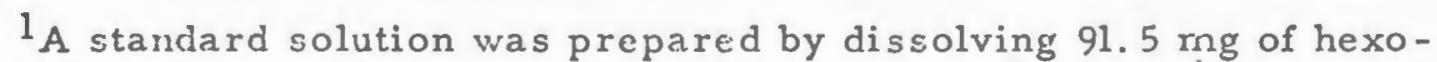
barbital in $200 \mathrm{ml}$ of cistilled water with $1.2 \mathrm{ml}$ of $1 \mathrm{~N} \mathrm{NaOH}$. Incubation inixture used $1.0 \mathrm{ml}(1.0,4 \mu$ Moles Hexobarbital $\mathrm{Na}$ ) of the standard solution in total volume of $4.0 \mathrm{ml}$.

${ }^{2}$ Prepared by aciding $8.5 \mathrm{ml}$ oi $0.119 \mathrm{Gm} \mathrm{Na} 2 \mathrm{HPO}_{4}$ in $10.0 \mathrm{ml}$ to $191.5 \mathrm{ml}$ of $1.820 \mathrm{Gm} \mathrm{KH}_{2} \mathrm{PO}_{4}$ in $200 \mathrm{ml}$ and washed with petroleum ether containing $1.5 \%$ isoaniyl al cohol. 
Thirty $\mathrm{ml}$ of washed petroleum ethe ${ }^{1}$ containing $1.5 \%$ isoamyl alcohol was added and the mixtures were shaken for 45 minutes and centrifuged for 10 minutes. Twenty $\mathrm{ml}$ aliquots of the solvent phase were transferred to clean tubes and shaken with $10.0 \mathrm{ml}$ of phosphate buffer $(\mathrm{pH}-11)^{2}$ for 10 minutes. The tubes were centrifuged and the petroleum ether was removed. The optical densities of the unmetabolized hexobarbital (aqueous phase) were determined at $245 \mathrm{m \mu}$ on a Beckman DB-G grating spectrophotometer. Two parallel incubation flasks were carried through the procedure, one containing $100 \mu \mathrm{gm}$ hexobarbital sodium (standard) with boiled tissue and the other containing tissue but no hexobarbital sodium to serve as the blank. Determination of In Vitro Metabolism of Zoxazolamine

The in vitro hydroxylation of zoxazolamine was measured by the method of Juchau et al., (1965). The basic incubation mixture and conditions as previously described were used with semicarbazide omitted and zoxazolamine ${ }^{3}$ as the substrate. After incubation, $2.0 \mathrm{ml}$

${ }^{1}$ Solvents were purified by washing with $1 \mathrm{~N} \mathrm{NaOH}, 1 \mathrm{~N} \mathrm{HCl}$ and two washings with distilled water. A technical grade of petroleum ether was adequate but a reagent grade of isoamyl alcohol was needed.

2 Prepared by adding $8.5 \mathrm{Gm}$ of $\mathrm{NaOH}$ to $500.0 \mathrm{ml}$ of $0.8 \mathrm{M} \mathrm{Na}_{2} \mathrm{HPO}_{4}$ anhydrous.

3 A standard solution was prepared by dissolving $50.0 \mathrm{mg}$ of zoxazol arnine in $50 \mathrm{ml}$ of $0.1 \mathrm{M}$. phosphate buifer (pH 7.4) with a small amount of $0.1 \mathrm{~N} \mathrm{HCl}$. Incubation mixture used $0.5 \mathrm{ml}(3.0 \mu \mathrm{Moles} z o x a z o l-$ amine) of the standard solution in a total volume of $5.0 \mathrm{ml}$. 
of the incubate was shaken with $25.0 \mathrm{ml}$ of heptane containing $1.5 \%$ isoamyl alcohol and $0.5 \mathrm{ml}$ of $1.0 \mathrm{~N} \mathrm{NaOH}$ for 30 minutes and centrifuged for 5 minutes. Twenty $\mathrm{ml}$ of the heptane layer was pipetted into a second centrifuge tube containing $7.0 \mathrm{ml}$ acetate buffer ( $\mathrm{pH}$ 5.6), shaken for 5 minutes, and centrifuged for 5 minutes. Fifteen $\mathrm{ml}$ of the heptane layer was shaken for 15 minutes with $7.0 \mathrm{ml}$ of $0.1 \mathrm{~N} \mathrm{HCl}$ and centrifuged for 15 minutes. The optical density of the aqueous phase was read at $278 \mathrm{mp}$ against a $0.1 \mathrm{~N} \mathrm{HCl} \mathrm{blank} \mathrm{on}$ a Beckman DB-G grating spectrophotometer. The amount of zoxazolamine metabolized was calculated as the difference in the amounts extracted from zero time (unincubated) and the incubated flasks.

Determination of Microsomal NADPH-Cytochrome c Reductase Activity

The system employed for the estimation of NADPH-cytochrome $c$ reductase was a modification of that described by Ernster et al. , (196?) and Dallner (1963). This assay is based on the determination of the rate of reduction of cytochrome $\leq$ through measurement of the absorbance increase of the reduced cytochrome at $550 \mathrm{m \mu}$.

Microsomal suspension containing $0.5 \mathrm{me} / \mathrm{ml}$ of protein in $0.05 \mathrm{M}$ phosphate buffer $(\mathrm{pH} 7.4)$ were employed for this assay. The assay system contained $0.67 \mu$ Moles NADPH, $0.33 \mu$ Moles cytochrome $\underline{c}$, and $0.99 \mu$ Moles $\mathrm{KCN}$ in $0.05 \mathrm{M}$ phosphate buffer (pH 7.4) 
in a total volume of $3.0 \mathrm{ml}$. The se reagents were placed in both the reference and sample cuvettes of a Beckman DB-G grating spectrophotometer equipped with a thermostatic cell compartment held at $37^{\circ} \mathrm{C}$ and a Beckman linear-log potentiometric recorder (Model 1005). A $0.1 \mathrm{ml}$ aliquot $(0.05 \mathrm{mg}$ of protein) of microsomal suspension was introduced into the sample cuvette and mixed. The linear change in absorbance over a 5 minute period at $550 \mathrm{m \mu}$ was recorded. An extinction coefficient of $18.5 \times 10^{3}$ at $550 \mathrm{mp}$ for reduced minus oxidized cytochrome c (Margoliash, 1954) was used in the calculations. The results were expressed as $\mu$ Moles of cytochrome $c$ reduced per minutes per mg microsomal protein.

Determination of CO-Binding Pigment $(P-450)$

The system employed for the estimation of $\mathrm{CO}$-binding pigment (cytochrome P-450) was similar to that described by Dallner (1963). The assay was conducted in a Cary Model 15 recording spectrophotometer.

To $6.0 \mathrm{ml} \mathrm{microsomal} \mathrm{suspension} \mathrm{(prepared} \mathrm{in} 0.05 \mathrm{M}$ phosphate buffer ( $\mathrm{pH} \mathrm{7.4)} \mathrm{to} \mathrm{contain} 1 \mathrm{mg}$ protein/ml) a few $\mathrm{mg}$ of $\mathrm{Na}$ dithionate were added to reduce the microsomal pigments. Three $\mathrm{ml}$ of microsomal suspension were placed into each of 2 cuvettes and the spectrum recorded from 500 to $400 \mathrm{mp}$. Carbon monoxide was bubbled through the sample cuvette for a period of 1 minute. The spectrum was again scanned from 500 to $400 \mathrm{m \mu}$ and the absorbance 
recorded. The absorbance at $500 \mathrm{mp}$ and at $450 \mathrm{m \mu}$ was taken from the recording and the content of the $\mathrm{CO}$-binding pigment was expressed as the difference in absorbance between 450 and $500 \mathrm{mp}$ per $\mathrm{rng}$ of microsomal protein.

\section{Statistical Methods}

Student's $t$ test (Dixon and Massey, 1957) was used to test for differences between means throughout this investigation. The formula employed is as follows:

$$
t=\frac{x_{1}-x_{2}}{s_{p} \frac{\left(n_{1}+n_{2}\right)}{n_{1} n_{2}}}
$$

where; $\quad s_{p}^{2}=\frac{\left(n_{1}-1\right) s_{1}^{2}\left(n_{2}-1\right) s_{2}^{2}}{n_{1}+n_{2}-2}$

$$
\begin{aligned}
& \mathrm{x}_{1}=\text { control mean, } \mathrm{x}_{2}=\text { treatment mean } \\
& { }_{1}=\text { control sample size, } \mathrm{n}_{2}=\underset{\text { treatment }}{\text { size }} \\
& \mathrm{s}_{1}=\text { control variance, } \mathrm{s}_{2}^{2}=\text { treatment variance }
\end{aligned}
$$

Calculations were performed on an IBM 360 computer. The program was written in Fortran four language. The degrees of freedon were taken as $n_{1}+n_{2}-2$. The levels of $p$ were taken from appendix 5 (Dixon and Massey, 195i). 
IV. RESULTS

In all experiments rats were exposed to a methylchloroform atmosphere (about $2500 \mathrm{ppm}$ ) for 24 hours.

Methylchloroform Concentration in the Exposure Chamber. The concentration of methylchloroform versus the two flow meters was determined several times throughout the investigation. The flow rates used for all experiments $(0.2$ liters/minute diluted with 10 liters air/minute) corresponded to a chamber atmosphere content of about $2500 \mathrm{ppm}$.

\section{Methylchloroform Content of Rat Blood and Liver Following} 24 Hour Exposure. Methylchloroform was found to be highly concentrated in the liver $(127 \mathrm{ppm})$ in contrast to the blood $(12.5 \mathrm{ppm})$ of rats exposed to the methylchloroform vapor (about $2500 \mathrm{ppm}$ ) for 24 hours (Table 1). Control experiments established that no methylchloroform was lost from blood samples collected and stored in a freezer before extraction with toluene. A peak corresponding to methylchloroform was observed in control samples although these animals had no known exposure to methylchloroform. This peak corresponds to instrument sensitivity.

All of the following data were obtained 24 hours after termination of a 24 hour period of exposure to the methylchloroform atmosphere. 
TABLE 1

ANALYSIS OF METHYLCHLOROFORM IN THE BLOOD AND LIVER

OF MALE RATS

\begin{tabular}{|c|c|c|}
\hline & $\mu g / g^{1}$ & $\mathrm{~m} \mu$ Moles /gm \\
\hline \multicolumn{3}{|l|}{ Liver } \\
\hline Controls (3) & $<0.1$ & $<0.7$ \\
\hline Treated $^{2}$ & $127.3 \pm 8.7^{3}$ & $954.3 \pm 65.1$ \\
\hline Blood & $\mu \mathrm{g} / \mathrm{ml}$ & mpMoles/gm \\
\hline Controls (7) & $<0.1$ & $<0.7$ \\
\hline Treated (8) & $12.5 \pm 2.3$ & $93.7 \pm 17.2$ \\
\hline \multicolumn{3}{|c|}{$\begin{array}{l}{ }^{1} \mathrm{Ug} / \mathrm{gm} \text { were determined by gas chromatography using an Aero- } \\
\text { graph Hi Fi Chromatograph Model } 600^{-} \mathrm{D} \text {. }\end{array}$} \\
\hline \multicolumn{3}{|c|}{$\begin{array}{l}3 \text { Results are expressed as mean values } \pm \text { standard error. } \\
\text { Number of samples is in parentheses. }\end{array}$} \\
\hline
\end{tabular}


Effect of Methylchloroform on Hcxobarbital Sleeping Time and Hexobarbital Oxidase

Hexobarbital sleeping time was significantly $(p<0.001)$ decreased $(70 \%)$ in rats exposed to methylchloroform vapors (Table $2 \mathrm{~A}$ ). In other experiments, decreases ranging from 45-80\% were observed. Significant $(p<0.001)$ increases of $30 \%$ in hexobarbital oxidase were observed in hepatic $9000 \times$ G supernate of rats exposed to methylchloroform (Table $2 \mathrm{~B})$. These results are in agreement with experiments performed in mice (Lal and Shah, 1968).

Effect of Methylchloroform on Zoxazolamine Sleeping Time and Zoxazolamine Hyd roxylase Activity

Zoxazolamine sleeping time was significantly $(p<0.01)$ decreased by $55-60 \%$ in rats exposed to methylchloroform (Table $3 \mathrm{~A}$ ). This was accompanied by a $20 \%$ increase $(p \leqslant 0.05)$ in in vitro microsomal zoxazolamine hydroxylase activity (Table $3 B$ ).

\section{Effects of Methylchloroform on Several Hepatic Microsomal Para-} meters of Drug Mctabolism

The liver/body weight ratio was significantly $(p<0.05)$ increased by $29 \%$. The trend in the experiments was for an increase of $20-30 \%$ in the ratio, but an increase was dernonstrated in only half the experiments. As far as microsomal protein per weight of liver, this ratio never increased. 
TABLE 2A

EFFECT OF METHYLCHLOROFORM ON HEXOBARBITAL SLEEPING TIME IN.THE MALE RAT

\begin{tabular}{l}
\hline $\begin{array}{l}\text { Slejeping time }{ }^{1} \\
\text { (min. } \pm \mathrm{S} . \mathrm{E} .)^{2}\end{array}$ \\
Controls \\
Methylchloroform ${ }^{3}$ \\
$\quad 26.2 \pm 3.0$
\end{tabular}

TAB LE 2B

EFFECT OF METHYLCHLOROFORM ON THE METABOLISM OF HEXO-

BARBITAL IN RAT LIVER $9000 \times$ G SUPERNATANTS

\begin{tabular}{ll}
\hline & $\mu$ Moles $/ g m$ liver $/ 30$ min. \pm S. E. \\
Controls & $2.541 \pm 0.061$ \\
Methylchloroform & \\
& $3.365 \pm 0.096^{*}$
\end{tabular}

1 Results are expressed as the mean values obtained from 10 animals \pm standard error.

2 Methylchloroform animals expcsed to atmospheric concentrations of about 2500 ppm methylchloroform for $2 \dot{4}$ hours.

$* p<0.001$. 
TABLE 3A

EFFECT OF METHYLCHLOROFORM EXPOSURE ON ZOXAZOLAMINE

SLEEPING TIME IN THE MALE RAT

\begin{tabular}{lll}
\hline & $\begin{array}{l}\text { Sleeping time } \\
\text { (min. } \pm \text { S. E. })^{2}\end{array}$ & \\
& Control & $\mathrm{MC}^{3}$ \\
Expt \#1 & $124 \pm 20.5(7)$ & $56 \pm 6.8^{*}(6)$ \\
Expt \#2 & $106 \pm 17.5(7)$ & $42 \pm 5.5^{*}(7)$ \\
\hline
\end{tabular}

1 Sleeping time taken as duration of loss of righting reflex. (Zoxazolamine $80 \mathrm{mg} / \mathrm{kg}$ ).

2 Results are expressed as the mean values \pm standard error with size in parentheses.

$3 \mathrm{MC}=$ methylchloroform animals exposed to atmospheric concentrations of about $2500 \mathrm{ppm}$ methylchloroform for 24 hours.

* $P<0.01$

TABLE 3B

EFFECT OF METHYLCHLOROFORM ON ZOXAZOLAMINE HYDROXY LASE ACTIVITY IN THE MAIJE RAT

\begin{tabular}{|c|c|c|}
\hline \multirow[t]{2}{*}{. } & \multicolumn{2}{|c|}{$\begin{array}{l}\text { mpMoles } / \mathrm{mg} \text { microsomal protein } / 30 \mathrm{~min} \text {. } \\
\pm \mathrm{S} . \mathrm{E} .1\end{array}$} \\
\hline & Control & $\mathrm{MC}^{2}$ \\
\hline Expt \# 1 & $210.9 \pm 13.2$ & $256.1 \pm 14.4^{*}$ \\
\hline Expt \#2 & $177.8 \pm 2.7$ & $216.6 \pm 12.5^{*}$ \\
\hline
\end{tabular}


Further examination of Table 4 indicated the typical significant $(\mathrm{p}<0.001)$ increases in CO-binding pigment $(\mathrm{P}-450)$ and NADPH cytochrome c reductase activity by 40 and $34 \%$, respectively. Spectral peaks of $\mathrm{P}-450$ for both control and nethylchloroform treated samples were the same, at about $451 \mathrm{mp}$.

A $62 \%$ significant $(p<0.001)$ increase in demethylation of aminopyrine in the same group of rats was also noted. In other experiments $40-80 \%$ increases $(p<0.001)$ in the metabolism of aminopyrine we re observed.

Effects of Cycloheximide on Various Parameters of Hcpatic Drug Metabolism in the Male Rat

Cycloheximide, an extra-nuclear protein inhibitor, was used to prevent the decrease in hexobarbital sleeping time and increase in in vitro metabolism of aminopyrine. The data in Table 5 indicate that the significant decreases in hexobarbital sleeping time and significant increases in demethylation of aminopyrine caused by methylchloroform treatment, can be blocked by pretreatment with cycloheximide.

Data for liver weight and supernatant protein are also presented in Table 5. The methylchloroform plus cycloheximide group was not different from the methylchloroform plus saline group as far as weight of liver per weight of $r$ at ratios but was significantly decreased $(P<0.001)$ in supernatant protein per gram of liver. 
TABLE 4

EFFECTS OF METHYLCHLOROFORM ON SEVERAL HEPATIC MICROSOMAL CONSTITUENTS IN

TİE MALE RAT

\begin{tabular}{|c|c|c|c|c|c|}
\hline & $\begin{array}{l}\text { Wt. Liver per } \\
\text { Bndy Wt. ratio } \\
\text { (mg/gm } \pm \text { S.E. })^{l}\end{array}$ & $\begin{array}{l}\text { Microsomal } \\
\text { protein per } \\
\text { wt. live } r_{+} \text {ratio } \\
\text { (mg/gm }- \text { S.E.) }\end{array}$ & $\begin{array}{l}\text { CO-binding } \\
\text { Pigment (P-450) } \\
\left(\mathrm{A}_{450-500 / \mathrm{mg} / \mathrm{ml}}\right. \\
\text { protein } \pm \mathrm{S} . \mathrm{E} .)\end{array}$ & $\begin{array}{l}\text { NADPH-cyto- } \\
\text { chrome c re - } \\
\text { ductase ( } \mu \mathrm{M} / \mathrm{mg} \\
\text { protein/min } \pm \\
\text { S. E.) } \\
\text {. }\end{array}$ & $\begin{array}{l}\text { Demethylase } \\
\text { (aminopyrine) } \\
\text { (muMoles HCHO } \\
\text { mg protein) } \pm \\
\text { S.E. }\end{array}$ \\
\hline Control & $53.4 \pm 3.9$ & $15.2 \pm 1.2$ & $0.053 \pm 0.003$ & $0.333 \pm 0.018$ & $176.6 \pm 5.5$ \\
\hline $\mathrm{MC}^{3}$ & $68.7 \pm 3.3$ & $15.4 \pm 1.0$ & $0.074 \pm 0.003$ & $0.447 \pm 0.012$ & $286.5 \pm 17.5$ \\
\hline "p" value & $<0.05$ & $>0.5$ & $<0.001$ & $<0.001$ & $<0.001$ \\
\hline
\end{tabular}

1 Results are expressed as mean values from 6 animals \pm standard error.

$2 \mathrm{HCFO}=$ formaldehyde.

$3 \mathrm{MC}=$ Methylchloroform animals exposed to atmospheric concentrations of about 2500 ppm methylchloroform for 24 hours. 
TABLE 5

EFFECTS OF CYCIOHEYIMIDE ON VARIOUS PARAMETERS IN THE MALE RAT

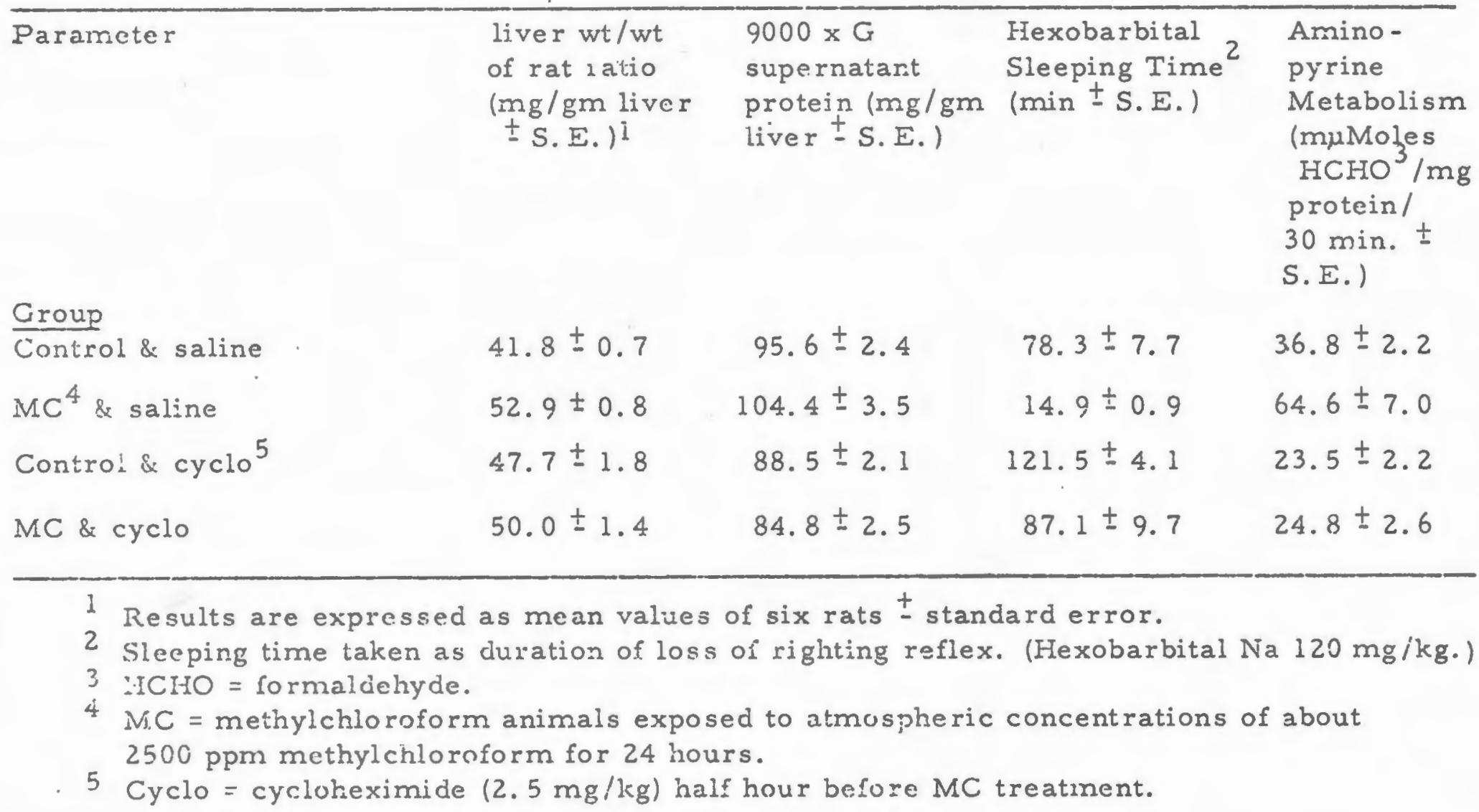


Effect of Actinomycin D on Hexobarbital Sleeping Time in the Male Rat Treatment with actinomycin D (protein irlibitor at the nuclear leve.1) at a dose of $40 \mu \mathrm{g} / \mathrm{kg} 30 \mathrm{~min}$. before methylchloroform trcatment and $40 \mu \mathrm{g} / \mathrm{kg} 12$ hours later did not prevent the significant decrease in hexobarbital sleeping time caused by incihylchloroform (Ta!sle 6A).

A dose of actinomycin D $80 \mu \mathrm{g} / \mathrm{kg} 30 \mathrm{~min}$. before methyl chloroform treatment and $40 \mu \mathrm{g} / \mathrm{kg} 12$ hours later caused a significant inhibition $(p<0.01)$ of the methylchloroform induced decrease in hexobarbital sleeping time (Table 6B). 
TABLE 6A

EFFECT OF ACTINOMYCIN D ON HEXOBARBITAL SLEEPING

TIME IN THE MALE RAT

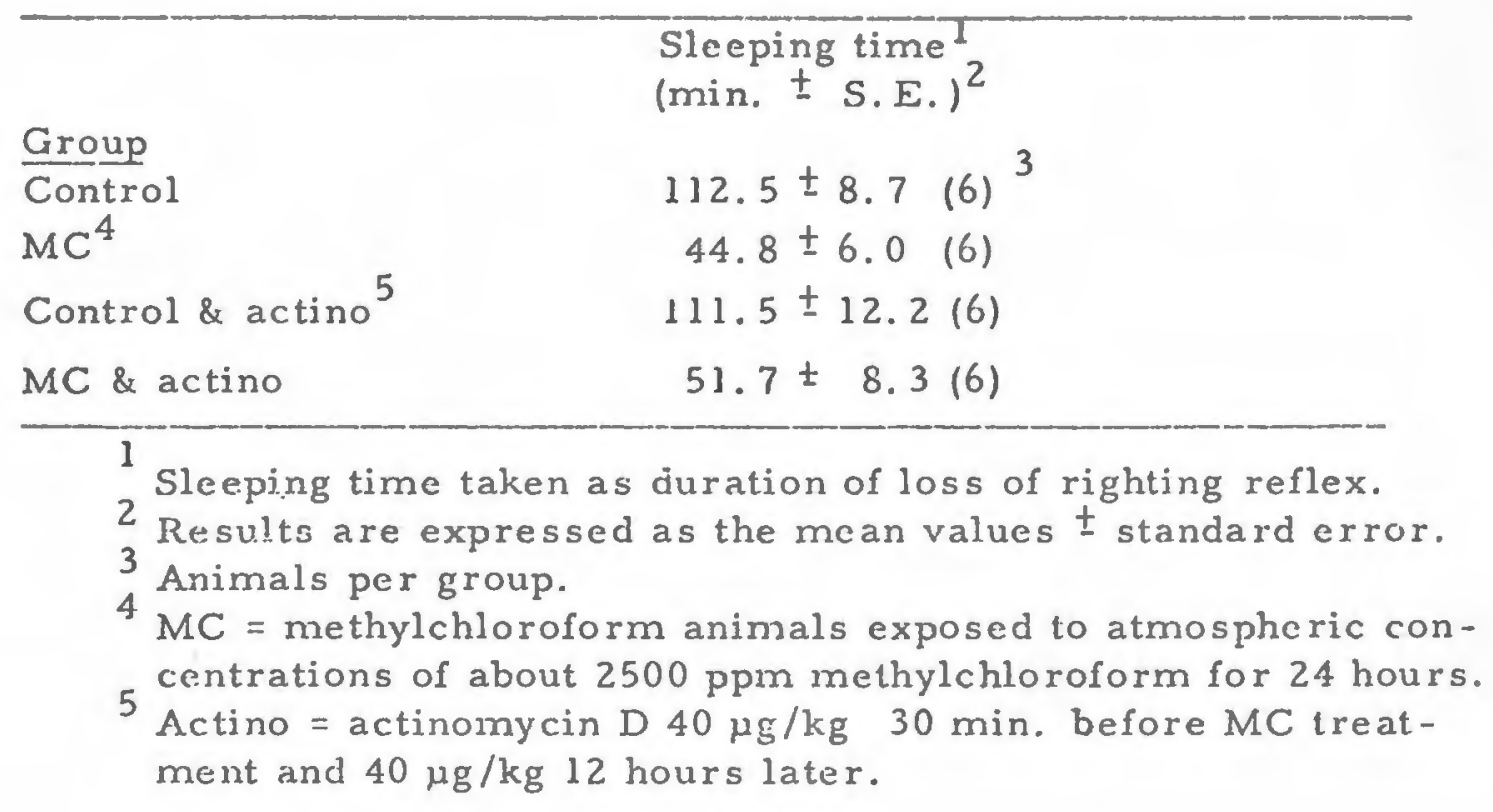

TABLE 6B

EFFECT OF ACTINOMYCIN D ON HEXOBARBITAL SLEEPING TIME IN THE MALE RAT

\begin{tabular}{|c|c|}
\hline & $\begin{array}{l}\text { Sleeping time } \\
\text { (min. }{ }^{\mathrm{I}} \mathrm{S} \text {. E.) }\end{array}$ \\
\hline$\frac{\text { Group }}{\text { control }}$ & $116 \pm 5.7(7)^{3}$ \\
\hline$M C^{4}$ & $48 \pm 2.1$ \\
\hline Control \& actino 5 & $118 \pm 4.2$ \\
\hline MC \& actino & $72 \pm 7.1 \quad(10)$ \\
\hline $\begin{array}{l}2 \text { Slecping tim } \\
3 \text { Results are } \\
4 \text { Animals pe } \\
\mathrm{MC}=\text { methy } \\
\text { centrations } \\
\text { Actino = ac } \\
\text { ment and } 4\end{array}$ & $\begin{array}{l}\text { ciuration of loss cf righting reflex. } \\
\text { as the mean values } \pm \text { standard error. } \\
500 \mathrm{ppm} \text { methylchloroform for } 2.1 \text { hours. } \\
\mathrm{D} 80 \mathrm{\mu g} / \mathrm{kg} 30 \mathrm{~min} \text {. before MC treat- } \\
\text { hours later. }\end{array}$ \\
\hline
\end{tabular}




\section{DISCUSSION}

This investigation indicated that hepatic drug-metabolizing enzymes in rats are stimulated by exposure to methylchloroform vapor. Methylchloroform was detected and measured in the liver and blood of exposed rats thus providing justification for a hypothesis that methylchloroform exerts a systemic effect. Studies by Stewart et al. (1961) in humans confirmed that methylchloroform blood concentrations are related to exposure.

Exposure to methylchloroform vapor significantly shortened hexobarbital and zoxazolamine sleeping time as do inducers of the phenobarbital type (Conney et al. , 1960) and anabolic steroid type (Booth and Gillette, 1962; Novick et al. , 1966). Inducers of the 3-methylcholanthrene type only reduce zoxazolamine sleeping time (Conney et al. , 1960).

In vitro parameters of drug metabolism (hexobarbital oxidase, aminopyrine $\mathrm{N}$-demethylase, and zoxazolamine hydroxylase) were significantly increased by methylchloroform exposure. Phenobarbital has been reported to cause increases in the same parameters (Conney et al., 1960; Kato and Takayanaghi, 1966). Anabolic steroids significantly increase the in vitro metabolism of hexobarbital and aminopyrine (Booth and Gillette, 1962; Kato and Takayanaghi, 1966), 
but do not significantly alter the hydroxylation of zoxazolamine (Gillettc, 1963; Kato and Takayanghi, 1966). 3-Methylcholanthrene increases the metabolism of zoxazolamine, but not aminopyrine or hexobarbital (Conney et al. , 1960; Kato and Takayanghi, 1966).

Methylchloroform significantly increased the levels of NADPHcytochrome c reductase and the content of CO-binding pigment (P-450) and did not change the spectral properties of the hemoprotein $(\mathrm{P}-450)$ when compared to controls. Treatment of rats with phenobarbital significantly increases the activity of the liver microsomal NADPH cytochrome c reductase (Jick and Shuster, 1960; Ernster and Orrenius, 1965) and the content of CO-binding pigment (Kuntzman et al. , 1968) without changing the spectral properties of this pigment. Kato and Takayanaghi (1966) and Von Der Decken and Hultin (1960) have demonstrated that treatment with 3-methylcholanthrene had no effect on NADPH-cytochrome $\subseteq$ reductase activity while Alvares et al. (1967) and Kuntzman et al. (1968) have shown increases in the content of CO-binding pigment, but with different spectral properties when compared to controls.

Inhibitors of protein synthesis have been demonstrated to block the increase in hepatic drug metabolism by known inducers. Pretreatment of animals with actinomycin D and cycloheximide prevented the induction of significant decreases in hexobarbital 
sleeping time by methylchloroform. The increase in the metabolism of aminopyrine was also blocked by cycloheximide pretreatment. These data support the hypothesis that the increase in drugmetabolizing enzymes of animals exposed to methylchloroform represents an induction of more enzyme protein. 


\section{SUMMARY AND CONCLUSIONS}

Rats were exposed for 24 hours to an atmospheric concentration of about 2500 PPM methylchloroform and in vitro and in vivo parameters of drug metabolism were measured 24 hours after the termination of exposure.

(1) Methylchloroform content was 10 -fold greater in the liver than the blood of exposed rats sacrificed immediately upon removal from the chamber. These findings suggest that methylchloroform acts systemically.

(2) Hexobarbital and zoxazolamine sleeping times were significantly decreased by exposure to methylchloroform vapor.

(3) In vitro metabolism of hexobarbital, zoxazolamine, aminopyrine, NADPH-cytochrome $c$ reductase, and content of $\mathrm{CO}$-binding pigment were significantly incrcased in animals exposed to methylchloroform.

(4) Actinomycin $D$ and cycloheximide blocked the methylchloroform induced decrease in hexobarbital sleeping time. Cycloheximide blocked the methylchloroform induced increase in demethylation of aminopyrine. These data suggest that the increase in the drugmetabolizing enzymes of the animals exposed to methylchlorofurir was mediated through the synthesis of protein.

(5) The spectrum of enzymes incluced by methy'lchloroform 
appears to be closely correlated with the spectrum of enzymes induced by phenobarbital. 


\section{BIBLIOGRAPHY}

Adams, E. M., Spencer, H. D., Rowe, V. K. and Irish, D. D.: Vapor toxicity of $1,1,1$-trichloroethane (methylchloroform) determined by experiments on laboratory animals. Arch. Ind. Hyg. 1:225-236, 1950.

Alvares, A. P., Schilling, F. R., Levin, W. and Kuntzman, R.: Studies on the induction of $\mathrm{CO}$-binding pigments in liver microsomes by phenobarbital and 3-methylcholanthrene. Biochem. Biophys. Res. Commun. 29:521-526, 1967.

Booth, J. and Gillette, J. R.: The effects of anabolic steroids on drug metabolism by microsomal enzymes in rat liver. J. Pharmacol. Exp. Therap. 137:374 - 379, 1962.

Browning, E.: Toxicity and metabolism of industrial solvents. Elsevier Publishing Company, New York, 1965.

Conney, A. H. : Pharmacological implications of microsomal enzyme induction. Pharmacol. Rev. 19:317-366, 1967.

Conney, A. H., Davison, C., Gastel, R. and Burns, J. J.: Adaptive increases in drug-metabolizing enzymes induced by phenobarbital and other drugs. J. Pharmacol. Exp. Therap. 130:1-8, 1960.

Conney, A. H., Miller, E. C. and Miller, J. A.: The metabolism of methylated amimoazo dyes. V. Evidence for induction of enzyme synthesis in the rat by 3 -methylcholanthrene. Cancer Res. 16: $450-459,1956$.

Cooper, D. Y., Levin, S., Narasimkulu, S., Rosenthal, O. and Estabrook, R. W.: Photochemical action spectrum of the terminal oxidase of mixed function oxidase systems. Science. 147:400-402, 1965.

Cooper, J. R. and Brodie, B. B.: Enzymatic oxidation of pentobarbital and thiopental. J. Pharmacol. Exp. Therap. 120:75-83, 1957. 
Dallner, G.: Studies on the structural and Enzymatic Organization of the membranous elements of liver microsomes. Acta. Path. Microbiol. Scand., Suppl. 166:7-41, 1963.

Dixon, W. J. and Massey, F. J.: Introduction to statistical analysis. McGraw-Hill Book Company, New York, 1957. 2nd edition.

Ernster, L. and Orrenius, S. : Substrate induced synthesis of the hydroxylating enzyme system of liver microsomes. Fed. Proc. 24: 1190-1199, 1956.

Garfinkel, D.: Studies on pig liver microsomes. I. Enzymatic and pigment composition of different microsomal fractions. Arch. Biochem. Biophys. 77:493-509, 1958.

Gelboin, H. V. and Blackburn, N.R.: The stimulatory effect of 3-methylcholanthrene on benzpy rene hydroxylase activity in several rat tissues. Inhibition by actinomycin D and puromycin. Cancer Res. 24:356-360, 1964 .

Gillette, J. R. : Factors that affect the stimulation of the microsomal drug enzymes induced by foreign compounds. Advance. Enzyme Regulation 1:215-223, 1963.

Hake, C. L., Waggoner, T. B., Robertson, D. N. and Rowe, V. K.: The metabolism of 1,1,1-trichloroethane by the rat. Arch. Environ. Health. 1:101-105, 1960 .

Harris, C. Reddy, J. and Svoboda, D: The effect of cycloheximide on ribonucleic acid and protein synthesis in rat liver. Biochem. Pharmacol. 18:951-954, 1969.

Imai, Y. and Sato, R.: Evidence for two forms of P-450 hemoprotein in microsomal membranes. Biochem. Biophys. Res. Commun. 23: $5-11,1966$.

Jick, H, and Shuster, L.: The turnover of microsomal reduced nicotinamide adenine dinuclcoticle phosphate-cytochrome c reductase in the livers of mice treated with phenobarbital. J. Biol. Chem. 241:53́6 -5369, 1966 .

Juchau, M. R., Cram, R. I., Plaa, G. L. and Fouts, J. R.: The induction of benzpyrene hydroxylase in the isolated perfused rat liver. Biochem. Pharmac. 114: 473-482, 1965. 
Kato, R. and Takayanaghi, M.: Differences among the action of phenobarbital, methylcholanthrene and male sex hormone on microsomal drug-metabolizing enzyme systems of rat liver. Jap. J. Pharmacol. 16:380-390, 1966.

Klingenberg, M.: Pigments of rat liver microsomes. Arch. Biochem. Biophys. $\underline{75: 376-386,1958 .}$

Korner, A. : Effect of cycloheximide on protein biosynthesis in rat liver. Biochem. J. 101:627-631, 1966.

Kuntzman, R., Levin, W., Jacobson, M. and Conney, A. H. : Studies on microsomal hydroxylation and the demonstration of a new carbon monoxide binding pigment in liver microsomes. Life Sci. 7-215-224, 1968.

Lal, H. and Shah, H.: Reduced sleeping time and increased microsomal oxidation of hexobarbital afte $r$ methylchloroform (MC) inhalation in mice. Pharmacologist. 10:153-159, 1968.

Lowry, O. H., Rosebrough, N. J., Farr, A. L. and Randall, R. J : Protein measurement with the folin phenol reagent. J. Biol. Chem. $193: 265-275,1951$.

McMahon, R. E. and Easton, N. R. : The N-demethylation of butynamine. J. Pharmacol. Exp. Therap. 135:128-133, 1962.

Margoliash, E.: The chromatographic behavior of cytochrome c on cation exchangers. Biochem. J. 56:535-543, 1954.

Mason, H. S.: Mechanisms of Oxygen Metabolism. Science 125: $1185-1188,1957$.

Novick, W. J., Jr., Stohler, C. M. and Swagzdig, J.: The influence of steroids on drug metabolism in the mouse. J. Pharmacol. Exp. The rap. 15]:139-142, 1966.

Omura, $T$, and Sato, R.: The carbon monoxide-binding pigment of liver microsomes. J. Biol. Chem. 239:2370-2385, 1964.

Orrenius, S., Ericsson, J. L. E. and Ernster, L.: Phenobarbital induced synthesis of the microsomal drug-metabolizing enzyme system and its relationship to the proliferation of encloplasrnic membranes: a morphological and biochemical study. J. Cell Biol. 25: $627-639,1965$. 
Reich, E., Franklin, R. M. Shaktin, A. J. and Tatum, E. L.: Effect of actinom ycin D on ecllular nucleic acid synthesis and virus production. Science (N. Y.) 134:556-557, 1961.

Reich, E. : Actinomycin: correlation of structure and function of its complexes with purines and DNA. Science. 143:684-689, 1964.

Remmer, H. and Merker, H. J.: Effect of drugs on the formation of smooth endoplasmic reticulum and drug-metabolizing enzymes. Ann. N. Y. Acad. Sci. 123:79-97, 1965.

Rennick, B. R. , Malton, S. C., Moe, G. K. and Seevers, M. H. : Induction of idioventricular rhythms of 1,1,1-trichloroethane and epinephrine. Fed. Proc. 8:327, 1949.

Rubin, A., Tephly, T. R. and Mannering, G. J.: Kinetics of drug metabolism by hepatic microsomes. Biochem. Pharmacol. 13: $1007-1016,1964$.

Siekevitz, P.: Origin and Functional Nature of Microsomes. Fed. Proc. 24:1153-1155, 1965.

Sladek, N. E. and Mannering, G. J.: Evidence for a new P-450 hemoprotein in hepatic microsomes from methylcholanthrene-treated rats. Biochem. Biophys. Res. Commun. 24:668-674, 1966.

Stewart, R. D., Gay, H. H., Erley, D. S., Hake, C. L. and Schaffer, A. W.: Human exposure to 1,1,1-trichloroethane vapor: Felationship of expired air and blood concentrations to exposure and toxicity. Am. Ind. Hyg. Assoc. J. 22:252-262, 1961.

Torkelson, T. R., Oyen, F., McCollister, D. D. and Rowe, V. K. : Toxicity of 1, 1,1-trichloroethane as determined by laboratory animals and human subjects. Am. Ind. Hyg. Assoc. J. 19:353-363, 1958.

Trakatellis, A. C. and Montjar, M. J.: Effect of cycloheximide on ribosome formation in the mouse liver. Life Sci. $1: 413-419,1968$.

Villa-Trevino, S., Shull, K. H. and Farber, E.: The role of adenosine triphosphate deficiency in ethionine induced inhibition of protein synthesis. J. Biol. Chem. 238:1757-1763, 1963. 
Von Der Decken, A. and Hultin, T.: Inductive effects of 3-methylcholanthrene on enzyme activities and amino acid incorporation capacity of rat liver microsomes. Arch. Biochem. Biophys. 90: $201-207,1960$.

Williams, R. T.: Detoxification mechanism. Chapman and Hall, London, 1959. 2nd edition.

Yarmolinsky, M. B. and De La Haba, G. L.: Inhibition by puromycin of amino acid incorporation into protein. Proc. Nat. Acad. Sci. U.S.A. 45:1721-1729, 1959. 


\section{VITA}

Arnold Merwin Olshan was born on May 20, 1940 in Hillside, New Jersey, where he obtained his elementary and high school education. Mr. Olshan enrolled at Rutgers University in 1958 and received the Bachelor of Science degree in pharmacy in June, 1962. Mr. Olshan was employed at Warner Lambert from 1964 to 1967. He entered the Graduate School of the University of Rhode Island in September, 1967, whe re Mr. Olshan completed the requirements for the Master of Science degree in pharmacology in August, 1969.

Mr. Olshan is married to the former Judith Anne Silverman of Hiliside, New Jersey. He is a member of the American Pharmaceutical Association, Rho Chi, and Phi Sigma Society. Mr. Olshan is a registered pharmacist in New Jersey, New York, and Rhode Island.

Mr. Olshan has accepted a position as staff assistant in Proprictary Development at Warner Lambert Research Institute, Morris Plains, New Jersey. 